\title{
THE EFFECTS OF AGING ON CAPILLARY HEMODYNAMICS IN CONTRACTING RAT SPINOTRAPEZIUS MUSCLE
}

by

STEVEN W. COPP

B.S., Kansas State University, 2006

\begin{abstract}
A THESIS
submitted in partial fulfillment of the requirements for the degree
\end{abstract}

MASTER OF SCIENCE

Department of Kinesiology

College of Arts and Sciences

KANSAS STATE UNIVERSITY

Manhattan, Kansas

2008

Approved by:

Major Professor

Timothy I. Musch, Ph.D. 


\begin{abstract}
Advancing age alters the structural and functional determinants of convective and diffusive muscle oxygen $\left(\mathrm{O}_{2}\right)$ flux. However, capillary red blood cell (RBC) hemodynamics have not been investigated during contractions in muscles of old animals. PURPOSE: To test the hypothesis that aging induces significant alterations in capillary hemodynamics during electrically-induced contractions in the spinotrapezius muscle of old Fischer 344 x Brown Norway rats when compared to younger counterparts.

METHODS: The spinotrapezius muscle was observed via intravital microscopy in 8 old (O: 26-30 months) and 5 young (Y: 6-8 months) animals. Wire electrodes elicited $1 \mathrm{~Hz}$ (6-8 volts) contractions for 3 minutes. $\mathrm{RBC}$ flux $\left(\mathrm{F}_{\mathrm{RBC}}\right)$, velocity $\left(\mathrm{V}_{\mathrm{RBC}}\right)$, capillary hematocrit $\left(\mathrm{H}_{\mathrm{CAP}}\right)$, and total microvascular $\mathrm{O}_{2}$ delivery $\left(\dot{Q} \mathrm{O}_{2 \mathrm{~m}}\right)$ were measured both at rest and during the steady-state of muscle contractions. RESULTS: At rest $\mathrm{F}_{\mathrm{RBC}}$ and $\mathrm{V}_{\mathrm{RBC}}$ were elevated in $\mathrm{O}$ compared to $\mathrm{Y}$ rats, while there was no difference in $\mathrm{H}_{\mathrm{CAP}}$ or $\dot{Q} \mathrm{O}_{2 \mathrm{~m}}$ between groups. During the contracting steady-state, $\Delta \mathrm{F}_{\mathrm{RBC}}(\mathrm{Y}: 28.8 \pm 7.7, \mathrm{O}:-$ $2.9 \pm 1.4$ cells $/ \mathrm{s}), \Delta \mathrm{V}_{\mathrm{RBC}}(\mathrm{Y}: 253 \pm 68, \mathrm{O}:-4 \pm 15 \mu \mathrm{m} / \mathrm{s}), \Delta \mathrm{H}_{\mathrm{CAP}}(\mathrm{Y}: 0.02 \pm 0.02, \mathrm{O}:-0.03$ \pm 0.01 cells $/ \mu \mathrm{m})$, and $\Delta \dot{Q} \mathrm{O}_{2 \mathrm{~m}}(\mathrm{Y}: 892 \pm 255, \mathrm{O}:-24 \pm 30 \mathrm{cells} / \mathrm{s} / \mathrm{mm})$ cells $/ \mathrm{s} / \mathrm{mm}$ were all lower $(P<0.05)$ in $\mathrm{O}$ compared to $\mathrm{Y}$ rats. CONCLUSION: These results indicate that despite maintained total convective and diffusive $\mathrm{O}_{2}$ transport at rest, advancing age results in significant alterations in capillary hemodynamics during electrically-induced contractions. These alterations likely contribute to the mechanisms responsible for the reduced exercise capacity commonly found in elderly populations.
\end{abstract}




\section{Table of Contents}

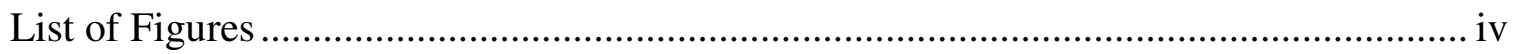

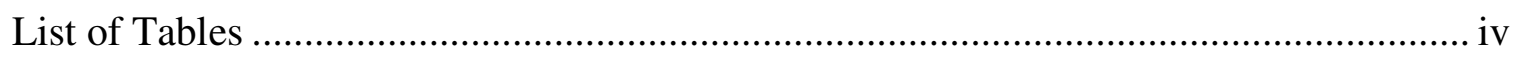

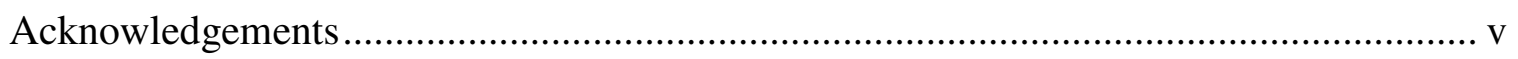

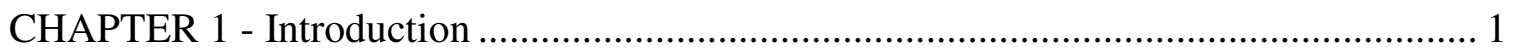

CHAPTER 2 - Review of Literature......................................................................... 4

Effects of age on functional capacity and muscle fatigue ............................................ 4

Aging-induced alterations in exercise hyperemia...................................................... 4

Aging-induced alterations within the microvasculature ………..................................... 6

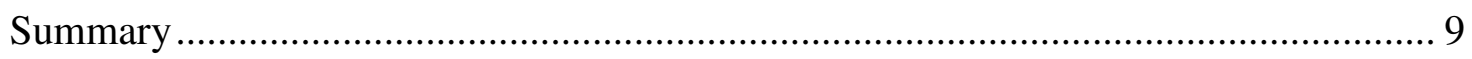

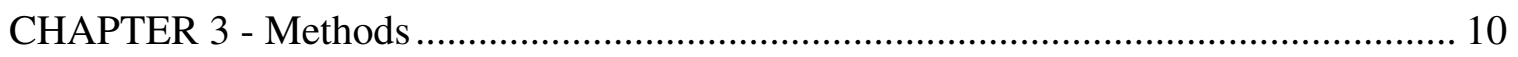

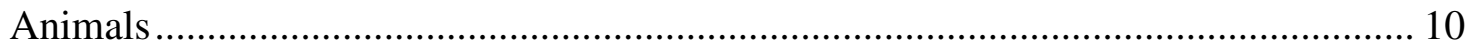

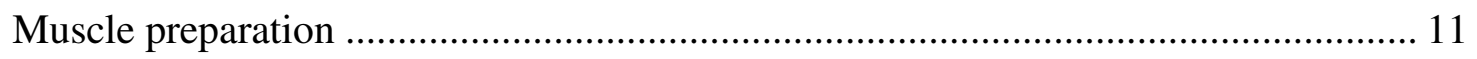

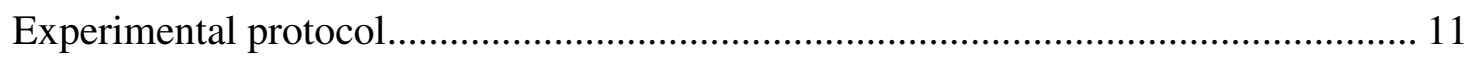

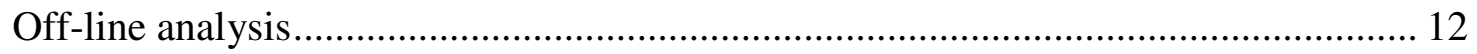

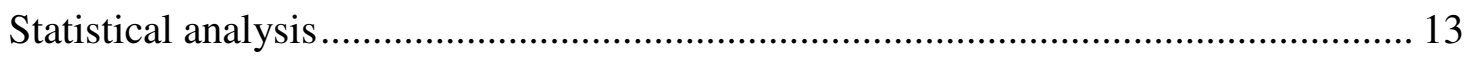

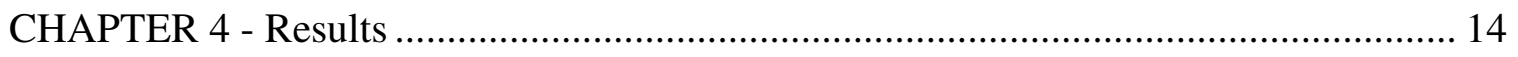

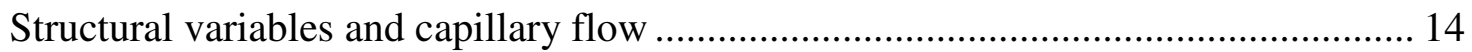

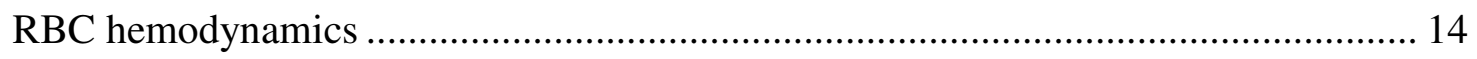

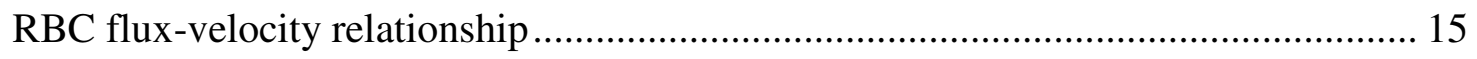

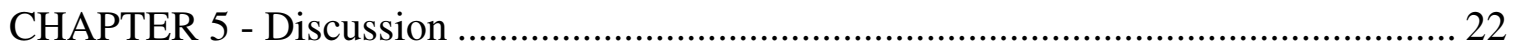

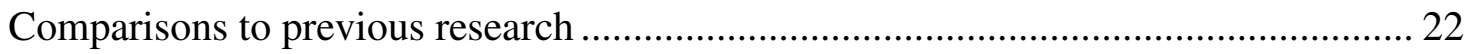

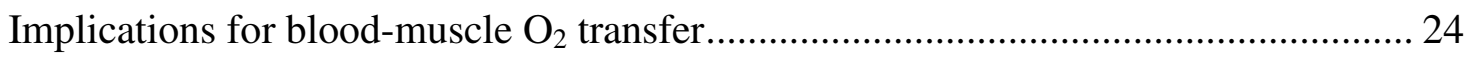

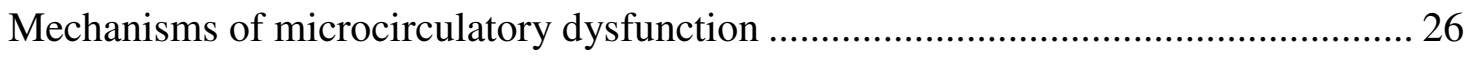

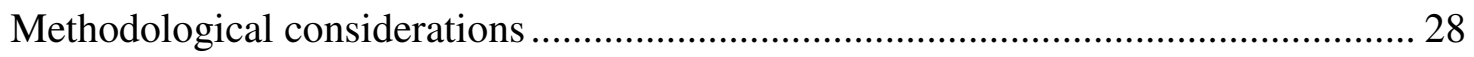

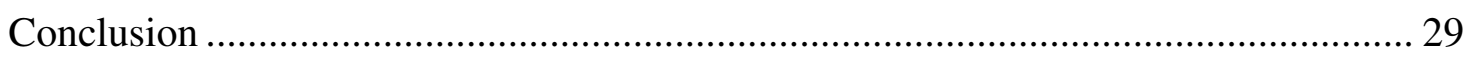

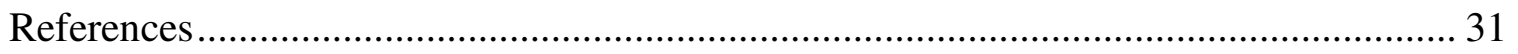




\section{List of Figures}

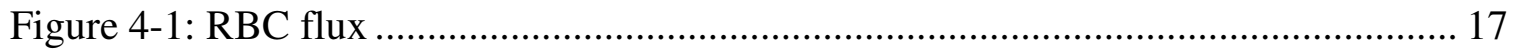

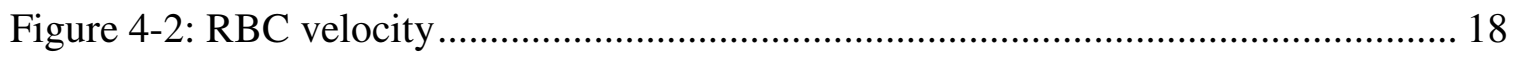

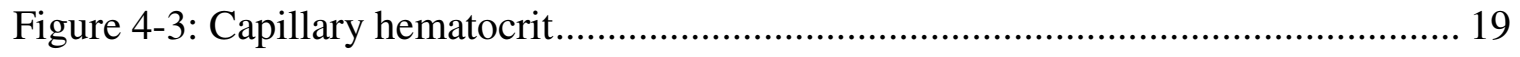

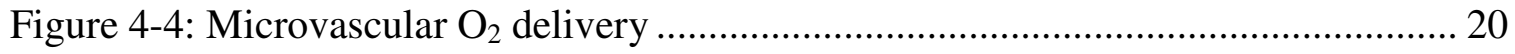

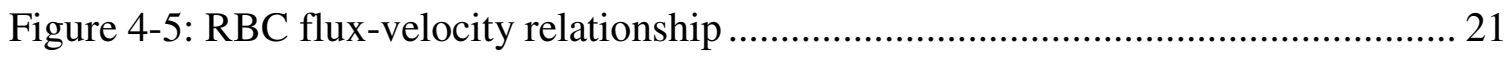

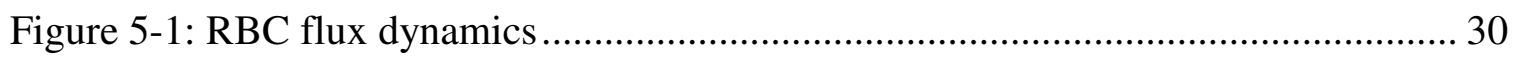

\section{List of Tables}

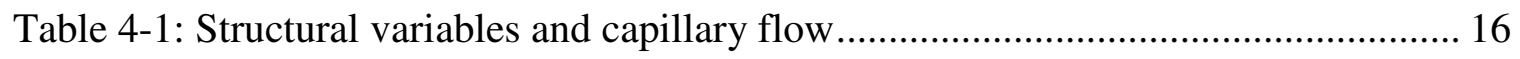




\section{Acknowledgements}

First and foremost, I would like to thank Drs Timothy Musch and David Poole for their mentorship and for allowing me to share in their enthusiasm for the scientific process. Additionally, I would like to thank Dr. Leonardo Ferreira for his guidance when I first ventured into the laboratory, as well as Dr. Thomas Barstow for his helpful insights pertaining to this study. I would also like to thank Sue Hageman, Kyle Herspring, Scott Hahn, Lauren Hammel, and Rob Davis for their technical assistance and indelible contribution to the fantastic laboratory environment. This work was supported by AHA Heartland Affiliate Grant-in-Aid to DCP and TIM. 


\section{CHAPTER 1 - Introduction}

Following maturation, advancing age is accompanied by both peripheral and central structural and functional alterations within the oxygen $\left(\mathrm{O}_{2}\right)$ transport pathway that lead to a decline in maximal exercise tolerance and muscle function. For example, the senescent myocardium may exhibit a reduced capacity to elevate cardiac output to meet the metabolic demands of exercise (Lakatta, 1990; Folkow \& Svanborg, 1993) and skeletal muscle perfusion may be compromised (Wahren et al., 1974; Irion et al., 1987). Recently, additional focus has been placed on a reduced ability of the aging skeletal muscle microcirculation to extract $\mathrm{O}_{2}$ despite maintained convective $\mathrm{O}_{2}$ delivery (McGuire et al., 2001; Hepple et al., 2003), thereby implicating an important peripheral component in the exercise intolerance of elderly individuals.

Within aging skeletal muscle there is a reduction in the number of feed arteries (Behnke et al., 2006) and capillaries as well as mitochondrial volume density (Conley et al., 2000). In addition, aging affects the myogenic control of vascular conductance (Musch et al., 2004; Behnke et al., 2006), reduces the bioavailability of nitric oxide (NO), and attenuates endothelium-dependent vasodilation (Muller-Delp et al., 2002b; Muller-Delp, 2006) resulting in a reduced ability to regulate vascular tone. These alterations are likely to contribute to the age-induced decrease in blood flow observed during dynamic leg exercise (Proctor et al., 1998) and electrically-induced muscle contractions (Hammer \& Boegehold, 2005), which may be accompanied by a redistribution of flow among different fiber types (Musch et al., 2004). Impaired active peripheral circulatory control results in temporal reduction of muscle $\mathrm{O}_{2}$ delivery relative 
to the $\mathrm{O}_{2}$ demands of exercise (Behnke et al., 2005). Until recently, capillary rarefaction was held responsible for the inability of aged muscles to extract $\mathrm{O}_{2}$ and sustain the transcapillary $\mathrm{O}_{2}$ fluxes found in their younger counterparts. However, recent reports of maintained or increased capillarity and total capillary-myocyte interface relative to mitochondrial oxidative capacity do not support the presence of a capillary structural limitation to $\mathrm{O}_{2}$ flux in aged muscle (Hepple \& Vogell, 2004; Mathieu-Costello et al., 2005). Given that the number of red blood cells (RBCs) along the capillary length at any given time serves as the primary determinant of tissue $\mathrm{O}_{2}$ diffusing capacity (Groebe \& Thews, 1990), alterations in microcirculatory hemodynamics and RBC distribution constitute a likely mechanism for the reduced $\mathrm{O}_{2}$ flux and, as such, may contribute to the exercise intolerance of the elderly.

To date, few studies have examined the effects of aging on microcirculatory hemodynamics, in part, because aging results in the proliferation of collagenous overgrowth and fascial attachments making optical clarity of the peripheral microcirculation difficult at best (Tyml et al., 1992; Russell et al., 2003). Recently, our laboratory has utilized a modified form of the rat spinotrapezius muscle preparation for observation of microvascular function via video microscopy in health (Kindig et al., 2002) disease (Kindig et al., 1999; Padilla et al., 2006) and aging (Russell et al., 2003) research. The spinotrapezius represents an excellent muscle for microscopic analysis due to its mixed fiber type composition (Delp \& Duan, 1996) and oxidative capacity similar to that of the human quadriceps (Leek et al., 2001). Resting measurements have demonstrated that aging reduces the lineal density of RBC-perfused capillaries, and increases $\mathrm{RBC}$ velocity $\left(\mathrm{V}_{\mathrm{RBC}}\right)$ and flux $\left(\mathrm{F}_{\mathrm{RBC}}\right)$ within the continuously perfused 
microvessels (see also (Tyml et al., 1992)) such that overall $\mathrm{F}_{\mathrm{RBC}}$ (i.e. microvascular $\mathrm{O}_{2}$ delivery, $\dot{Q} \mathrm{O}_{2 \mathrm{~m}}$ ) is maintained (Russell et al., 2003). Additionally, measurements of arteriolar blood flow in the aged spinotrapezius during electrically-induced contractions have revealed that contractions up to $2 \mathrm{~Hz}$ may not elicit increases in arteriolar flow in contrast to the several-fold increase this contraction protocol induces in young muscles (Hammer \& Boegehold, 2005). However, to our knowledge, analysis of the effects of aging on peripheral capillary hemodynamics during contractions are completely absent from the literature.

Therefore, the present investigation analyzed the spinotrapezius muscle of young (3-4 month old) and old (26-30 month old) Fischer 344 x Brown Norway rats to determine the effects of aging on capillary hemodynamics during electrically-induced contractions. We tested the following original hypotheses: 1) Aged rats would exhibit a significantly attenuated increase in $\mathrm{F}_{\mathrm{RBC}}$ and $\mathrm{V}_{\mathrm{RBC}}$ in response to contractions, and 2) the attenuated $\mathrm{F}_{\mathrm{RBC}}$ and $\mathrm{V}_{\mathrm{RBC}}$ will be associated with a blunted increase in capillary hematocrit $\left(\mathrm{H}_{\mathrm{CAP}}\right)$ and, by implication, reduce total $\mathrm{O}_{2}$ extraction in aged vs. young muscles. 


\section{CHAPTER 2 - Review of Literature}

\section{Effects of age on functional capacity and muscle fatigue}

Beyond physical maturation, aging is a process that is marked by a decline in exercise tolerance and the capacity to perform physical work. Specifically, aged individuals show a reduction in maximal $\mathrm{O}_{2}$ uptake $\left(\dot{\mathrm{V}}_{2 \max }\right)($ Ogawa et al., 1992) and a decreased power output and increased rate of muscle fatigue during repeated quadriceps contractions (Petrella et al., 2005). Aging-associated limitations in functional capacity and exercise tolerance have important implications for elderly populations where exercise may be a beneficial therapeutic intervention aimed at improving quality of life.

Alterations in functional capacity may be due to varying combinations of aging-induced derangements in the structure and/or function of both central and peripheral components of the $\mathrm{O}_{2}$ transport pathway. An elegantly-designed longitudinal study by McGuire and colleagues (McGuire et al., 2001) found that stroke volume is increased with age, thereby compensating for the aging-associated decline in maximal heart rate (HR) thereby maintaining maximal cardiac output. This important finding has shifted the focus of the search for the primary mechanistic basis of aging-induced decrements in exercise tolerance away from central adaptations towards aging-induced alterations in the periphery.

\section{Aging-induced alterations in exercise hyperemia}

It is generally accepted that, in healthy young individuals, muscle blood flow $\left(\dot{Q}_{\mathrm{m}}\right)$ to the submaximally exercising muscles is increased in such a fashion that the $\mathrm{O}_{2}$ 
delivery does not limit the $\dot{\mathrm{V}}_{2}$ of the exercising muscle $\left(\dot{\mathrm{V}}_{2 \mathrm{~m}}\right)$ either in the transition from rest to exercise or during the steady-state (Barstow et al., 1990; Grassi, 2000).

However, many studies have investigated the possibility of a reduction in $\dot{Q}_{\mathrm{m}}$ to active muscle with advancing age, which would act to limit exercise tolerance. For example, several studies have reported $\dot{Q}_{\mathrm{m}}$ reductions when comparing old rats to their younger counterparts during electrical stimulation of skeletal muscle (Irion et al., 1987; Hammer $\&$ Boegehold, 2005). Similarly, in humans, $\dot{Q}_{\mathrm{m}}$ to the active leg muscles is reduced during dynamic exercise in older men (Wahren et al., 1974; Proctor et al., 1998) and women (Proctor et al., 2003a). Recently, Donato et al. (Donato et al., 2006)

demonstrated that the difference in the leg $\dot{Q}_{\mathrm{m}}$ response to exercise found between young and old subjects was a product of the response to the exercise stimulus itself, as opposed to variations in resting $\dot{Q}_{\mathrm{m}}$ between age groups. Collectively, the results of the aforementioned studies are in conflict with other reports where no difference in $\dot{Q}_{\mathrm{m}}$ was found between young and old subjects during forearm exercise (Jasperse et al., 1994) or dynamic leg exercise (Olive et al., 2002; Proctor et al., 2003b). Specifically, Olive et al. (Olive et al., 2002) demonstrated that exercising $\dot{Q}_{\mathrm{m}}$ is a function of physical activity patterns but not age differences.

Despite contrasting reports concerning bulk blood flow in aged individuals, circulatory maladaptations may be occurring within the aged peripheral circulation that would reduce exercise capacity in the face of maintained bulk $\dot{Q}_{\mathrm{m}}$. For example, using radiolabeled microspheres, Musch et al. (Musch et al., 2004) reported no difference between young and old rats total limb $\dot{Q}_{\mathrm{m}}$ in response to treadmill running exercise. 
However, they were able to demonstrate that aging elicited a redistribution of $\dot{Q}_{\mathrm{m}}$ away from highly oxidative muscles towards highly glycolytic muscles. It is likely that the reduced $\dot{Q}_{\mathrm{m}}$ to the oxidative fibers seen during submaximal exercise is closely linked to the earlier onset of fatigue that is witnessed in the aged population via mismatching of the $\dot{Q}_{\mathrm{m}} / \dot{\mathrm{V}}_{2 \mathrm{~m}}$ ratio. In addition to $\dot{Q}_{\mathrm{m}}$ redistribution, middle-aged men may tend to elicit a higher mean arterial pressure (MAP) and lower vascular conductance $\left(\dot{Q}_{\mathrm{m}}=\mathrm{MAP} \mathrm{x}\right.$ vascular conductance) during exercise when compared with younger men (Magnusson $e t$ al., 1994; Lawrenson et al., 2003; Poole et al., 2003). The increase in perfusion pressure most likely reflects a heightened state of vasoconstriction (or reduced vasodilation) of the vessels supplying the working muscles (Proctor \& Parker, 2006). Overall, the redistribution of $\dot{Q}_{\mathrm{m}}$ away from the highly oxidative fibers as well as a lower vascular conductance and increased driving pressure most likely translates into alterations that impair skeletal muscle microvascular function during exercise in old subjects.

\section{Aging-induced alterations within the microvasculature}

Although central (Ogawa et al., 1992) and peripheral (Musch et al., 2004)

derangements to $\dot{Q}_{\mathrm{m}}$ certainly exist in aged individuals, the effect that these perturbations have on capillary-tissue $\mathrm{O}_{2}$ exchange is speculative at best without direct functional assessment of the peripheral microcirculation. Elegant modeling studies by Groebe and Thews (Groebe \& Thews, 1986) and Friederspiel and Popel (Federspiel \& Popel, 1986) have suggested that the total number of red blood cells that lie adjacent to a muscle fiber is the primary determinant of the diffusion capacity of $\mathrm{O}_{2}\left(\mathrm{DO}_{2}\right)$. In turn, the $\mathrm{DO}_{2}$ is a principle determinant of skeletal muscle $\mathrm{O}_{2}$ extraction. Alterations in either 
microcirculatory structural or functional capacity could account for limitations to $\mathrm{DO}_{2}$ with aging. However, reports by Hepple et al. (Hepple \& Vogell, 2004) and MathieuCostello et al. (Mathieu-Costello et al., 2005) have demonstrated that capillarity and, more specifically, the capillary-fiber-interface is either maintained or improved in aged animals relative to the fiber oxidative capacity, thereby implicating derangements in microvascular function.

Technological and ethical limitations have prevented direct observation of the peripheral i.e, muscle microcirculation in humans. Therefore, a rat model has commonly been employed to examine functional microcirculatory indices of $\mathrm{O}_{2}$ delivery including $\mathrm{F}_{\mathrm{RBC}}, \mathrm{V}_{\mathrm{RBC}}$, capillary hematocrit $\left(\mathrm{H}_{\mathrm{cap}}\right)$, capillary lineal density (number of capillaries per muscle width), countercurrent flow, and the partial pressure of $\mathrm{O}_{2}\left(\mathrm{PO}_{2}\right)$ in the microcirculation (Kindig et al., 1999; Kindig et al., 2002; Richardson et al., 2003; Russell et al., 2003; Behnke et al., 2005; Padilla et al., 2006). In the rat, one of the muscles commonly used to examine the microcirculation is the spinotrapezius muscle (Kindig et al., 1998; Kindig et al., 1999; Kindig \& Poole, 1999, , 2001; Kindig et al., 2002; Russell et al., 2003). The spinotrapezius muscle is located on the superficial dorsal region of the rat having its origin on the vertebral column and insertion on the scapula. The muscle is ideal for microcirculatory observation due to its mixed fiber type composition (Delp \& Duan, 1996) and oxidative capacity similar to that of human quadriceps muscle (Leek et al., 2001). Additionally, it can be readily exteriorized, there is an absence of fascia and large vessels obscuring the microvascular field, and it is very thin, making it suitable for transmission light microscopy. Using intravital microscopy, Russell et al. (Russell et al., 2003) was able to demonstrate that differences exist in 
capillary hemodynamics at rest between young and old rats. Specifically, in old rats the lineal density of capillaries sustaining $\mathrm{RBC}$ perfusion was decreased, while $\mathrm{V}_{\mathrm{RBC}}$ and $\mathrm{F}_{\mathrm{RBC}}$ were increased within the flowing capillaries. In addition, the number of capillaries demonstrating countercurrent flow, which provides for a higher average $\mathrm{PO}_{2}$ surrounding the myocyte (Kobayashi et al., 1990), was reduced. These alterations were such that convective $\dot{Q} \mathrm{O}_{2 \mathrm{~m}}$ (lineal density of flowing capillaries x mean $\mathrm{F}_{\mathrm{RBC}}$ ) at rest was not affected. The increased $\mathrm{V}_{\mathrm{RBC}}$ in aged rats supported the results of a previous investigation that reported an increased $\mathrm{V}_{\mathrm{RBC}}$ within the extensor digitorum longus muscle of old rats at rest (Tyml et al., 1992).

In contrast to resting microvascular flow measurements in aged skeletal muscle, measurements in contracting aged muscle have remained elusive primarily due to reductions in visual clarity of the muscle when viewed under magnification. Despite these limitations, Hammer and Boegehold (Hammer \& Boegehold, 2005) utilized the rat spinotrapezius muscle and made measurements of arteriolar flow in young and old animals in response to 3 minutes of electrically-induced contractions of varying frequencies $(.5,1$, and $2 \mathrm{~Hz})$. Their results demonstrated that up to $2 \mathrm{~Hz}$ contractions, aged rats elicited no consistent increase in arteriolar $\mathrm{V}_{\mathrm{RBC}}$ while consistent increases were observed in their younger counterparts. However, a significant limitation to the study was that, due to contraction-mediated disruption of the microvascular field, the $\dot{Q}_{\mathrm{m}}$ response was limited to assessment during the immediate post-contraction period. More importantly, functional determination of RBC hemodynamics in the skeletal muscle microcirculation, the site of peripheral gas exchange, is still lacking. The alterations in microcirculatory structure and function that exist in old rats at rest, and likely persist 
during contractions, may reflect alterations in peripheral vascular control (see Discussion) which impair $\mathrm{O}_{2}$ delivery and exchange during exercise, despite maintenance of these variables under resting conditions.

\section{Summary}

Aged individuals demonstrate reductions in $\dot{\mathrm{V}}_{2 \max }$ and impairments in muscle function. These maladaptations are consequent to a reduced $\dot{Q}_{\mathrm{m}}$, altered peripheral $\dot{Q}_{\mathrm{m}}$ distribution, and/or variation in the control of vascular conductance. While the effect that aging-induced alterations in peripheral $\mathrm{O}_{2}$ delivery have on skeletal muscle capillary $\mathrm{RBC}$ hemodynamics has been described at rest, to date, it is currently unknown if $\mathrm{RBC}$ capillary hemodynamics are altered in aged muscle during contractions. Analyzing peripheral microcirculatory alterations during contractions is important because it has direct implications for peripheral gas exchange during exercise and, therefore, the ability of aged individuals to sustain dynamic exercise. 


\title{
CHAPTER 3 - Methods
}

\begin{abstract}
Animals
A total of 13 animals, 8 old (26-30 months) and 5 young (6-8 months) male Fischer 344 x Brown Norway F1 hybrid (F344xBN) rats were used in the present investigation. These ages were chosen because they represent young adult (6-8 months) and senescent (26-30 months) rats in accordance with the lifespan of the F344xBN strain. Additionally, the F344xBN represents an ideal model to investigate the effects of healthy aging in that they are the result of a highly judicious breeding process designed to minimize the incidence of many typical aging-induced pathologies that might confound data interpretation. All rats were maintained on a 12:12 hour light-dark cycle and provided food and water ad libitum.

Animals were initially anesthetized with pentobarbital sodium (30-50 $\mathrm{mg} / \mathrm{kg}$ i.p. to effect), with supplementation as necessary throughout the duration of the protocol, and placed on a heating pad. Core temperature was measured via a rectal probe and maintained at $\sim 37^{\circ} \mathrm{C}$. A catheter (Intramedic polyethylene-50 connected to polyethylene-10 tubing, Clay Adams Brand, Sparks, MD) was placed in the aortic arch via the right carotid artery for continuous monitoring of MAP and HR throughout the experiment. Upon completion of each experiment, animals were euthanized via pentobarbital overdose. All experimental procedures were approved by the Kansas State University Institutional Animal Care and Use Committee.
\end{abstract}




\section{Muscle preparation}

The rat spinotrapezius muscle is a postural muscle, originating in the lowerthoracic and upper-lumbar region of the vertebral column and inserting on the scapula, which also functions to stabilize the scapula, for example, during downhill treadmill running (Kano et al., 2004). The left spinotrapezius muscle was exposed and exteriorized as described previously (Poole et al., 1997; Kindig et al., 2002; Russell et al., 2003), in a manner which preserves the vascular network and neural connections supplying the muscle (Bailey et al., 2000). Briefly, the caudal end of the muscle was isolated from its insertion and sutured at 5 equidistant points to a thin wire manifold and attached to a stretching and swivel apparatus. Thin stainless steel wire electrodes were sutured to both the peripheral caudal end and near the motor point on the more proximal ventral surface of the muscle, in a manner that elicited optimal muscle fiber shortening. The manifold was secured to the platform with the ventral aspect of the muscle reflected upwards for microscopic observation. Sarcomere length was initially set at $\sim 2.7 \mu \mathrm{m}$, which prevents stretch-induced flow attenuations and elicits normal physiological capillary flow (Kindig $\&$ Poole, 1999). Throughout the experiment, the spinotrapezius muscle was kept moist by constantly superfusing it with a Krebs-Henseleit bicarbonate-buffered solution equilibrated with $95 \% \mathrm{~N}_{2}-5 \% \mathrm{CO}_{2}$, and exposed surrounding tissue was covered with saran wrap (Dow Brands, Indianapolis, IN).

\section{Experimental protocol}

A microcirculatory field from the mid-caudal region of the spinotrapezius that provided optimal clarity for the visualization of a minimum of 5-6 capillaries was selected randomly for analysis. Images were obtained with an intravital microscope 
(Nikon Eclipse E600-Fn, Tokyo, Japan) equipped with a non-contact immersion lens (x40, numerical aperture 0.8 ) under a final magnification of $x 1,184$. Images were transmitted in real time to a high-resolution color monitor (Sony Trinitron, PVM-1954Q, Ichinoniya, Japan) and recorded (JVC S-VHS Master XG) for future off-line analysis via videocassette recorder (JVC BR-S822U, Elmwood Park, NJ). Resting data was obtained for 60 seconds, after which electrical stimulation ( $1 \mathrm{~Hz}$ twitch contractions, $2 \mathrm{~ms}$ duration, 6-8 volts) elicited muscle contractions for 180 seconds. These stimulation parameters were selected based on the fact that in young healthy rats, utilizing the same preparation, they are known to induce significant increases in microcirculatory hemodynamic and metabolic variables (i.e. 2-3 fold increases $F_{R B C}$ and $>4$ fold increase in $\dot{\mathrm{V}}_{2 \mathrm{~m}}$; Behnke et al., 2002; Kindig et al., 2002). Following the experimental protocol, $100 \mu \mathrm{l}$ blood samples were drawn for measurement of arterial blood gases, systemic hematocrit, $\mathrm{pH}$, and blood lactate concentrations. Both the right and left spinotrapezius muscles were carefully dissected, weighed, and frozen.

\section{Off-line analysis}

Capillary diameter $\left(\mathrm{d}_{\mathrm{C}}\right)$ was measured at rest using precision calipers at two different sites along each capillary where the endothelium was clearly visible. Sarcomere length was determined in each muscle fiber where 11 consecutive A-bands could be clearly distinguished. Capillary flow was observed in real-time and using frame-byframe analysis (30 frames/s). The percentage of vessels sustaining continuous RBC perfusion was determined as: (number of continuously RBC-perfused vessels $\div$ total number of vessels in a given muscle region) $\mathrm{x} 100 . \mathrm{F}_{\mathrm{RBC}}$ was measured as the number of RBCs passing an arbitrary point per second (cells/s), and $\mathrm{V}_{\mathrm{RBC}}$ was measured as $\mathrm{RBC}$ 
speed along the visible capillary length $(\mu / \mathrm{s})$. Both $\mathrm{F}_{\mathrm{RBC}}$ and $\mathrm{V}_{\mathrm{RBC}}$ were measured in all clearly visible capillaries, within the same frames (where possible), at rest and between 150-180s of contractions. This time-frame (i.e., 150-180s) was assumed to be the contracting steady-state based on the observation that in aged contracting spinotrapezius muscle, the microvascular $\mathrm{PO}_{2}$ does not change over an identical time period (Behnke et al., 2005). Where poor visual clarity did not allow $F_{R B C}$ and $V_{R B C}$ determination within the same frames, the hemodynamics were measured in as close temporal proximity as possible. In all capillaries where $\mathrm{F}_{\mathrm{RBC}}$ and $\mathrm{V}_{\mathrm{RBC}}$ were measured, capillary tube hematocrit $\left(\mathrm{H}_{\mathrm{CAP}}\right)$ was calculated as $\mathrm{H}_{\mathrm{CAP}}=\left(\mathrm{RBC}_{\mathrm{VOLUME}} \mathrm{x} \mathrm{F}_{\mathrm{RBC}}\right) \div\left[\pi \mathrm{x}\left(\mathrm{d}_{\mathrm{C}} / 2\right)^{2} \mathrm{x} \mathrm{V}_{\mathrm{RBC}}\right]$, where $\mathrm{RBC}_{\text {VOLUME }}$ was assumed to be $61 \mu \mathrm{m}^{3}$ (Altman \& Dittmer, 1974), and capillary cross-sectional shape was assumed to be circular in vivo (Mathieu-Costello et al., 1998). In some cases (particularly in aged muscles), poor clarity dictated measurement of $\mathrm{V}_{\mathrm{RBC}}$ and $\mathrm{H}_{\mathrm{CAP}}$ and the equation was rearranged to solve for $\mathrm{F}_{\mathrm{RBC}}$ (i.e. $\mathrm{F}_{\mathrm{RBC}}=\left(\left[\pi \mathrm{x}\left(\mathrm{d}_{\mathrm{C}} / 2\right)^{2}\right] \mathrm{x}\right.$

$\left.\left.\mathrm{V}_{\mathrm{RBC}} \times \mathrm{H}_{\mathrm{CAP}}\right) \div \mathrm{RBC}_{\text {VOLUME }}\right)$. $\dot{Q} \mathrm{O}_{2 \mathrm{~m}}$ to the whole muscle region at rest and the steadystate of contractions was calculated as the product of the lineal density of flowing capillaries x mean capillary $\mathrm{F}_{\mathrm{RBC}}$.

\section{Statistical analysis}

All data are presented as mean \pm SE. Means were compared with paired and unpaired Student's $t$-tests. The level of significance was set at $P \leq 0.05$. 


\section{CHAPTER 4 - Results}

MAP was not different between young $(\mathrm{Y})$ and old $(\mathrm{O})$ rats at rest $(\mathrm{Y}: 85 \pm 4$, O: $104 \pm 7 \mathrm{mmHg}, P>0.05)$ or during contractions (Y: $94 \pm 2, \mathrm{O}: 97 \pm 11 \mathrm{mmHg}, P>$ 0.05), and did not change from rest to contractions in either group.

\section{Structural variables and capillary flow}

Structural and general capillary flow data are presented in Table 4-1. The lineal density of capillaries was reduced $(P<0.05)$ while the percentage of capillaries supporting flow was similar $(P>0.05)$ in $\mathrm{O}$ compared to $\mathrm{Y}$ rats. As a result, there was an aging-induced reduction $(P<0.05)$ in the lineal density of capillaries supporting RBC flow at rest and during contractions. The percentage of capillaries exhibiting countercurrent flow was similar between groups $(P>0.05)$.

\section{RBC hemodynamics}

$\mathrm{F}_{\mathrm{RBC}}$ data is presented in Figure 4-1 for $\mathrm{Y}$ and $\mathrm{O}$ rats at rest and during contractions. During contractions, $\mathrm{F}_{\mathrm{RBC}}$ increased $(P<0.05)$ from resting values in $\mathrm{Y}$ but not in $\mathrm{O}(P>0.05)$. Thus, from rest to contractions, the $\Delta \mathrm{F}_{\mathrm{RBC}}(\mathrm{Y}: 28.8 \pm 7.7, \mathrm{O}:-2.9 \pm$ 1.4 cells/s, $P<0.05$ ) was lower in $\mathrm{O}$ rats. $\mathrm{V}_{\mathrm{RBC}}$ data is presented in Figure 4-2 and, similar to $\mathrm{F}_{\mathrm{RBC}}$, at rest $\mathrm{V}_{\mathrm{RBC}}$ was elevated in $\mathrm{O}$ rats while it was increased during contractions in $\mathrm{Y}(P<0.05)$ but not $\mathrm{O}(P>0.05)$ animals. Thus, from rest to contractions, the $\Delta \mathrm{V}_{\mathrm{RBC}}(\mathrm{Y}: 253 \pm 68, \mathrm{O}:-4 \pm 15 \mu \mathrm{m} / \mathrm{s}, P<0.05)$ was lower in $\mathrm{O}$ rats. $\mathrm{H}_{\mathrm{CAP}}$ (Figure 4-3) was similar $(P>0.05)$ between $\mathrm{Y}$ and $\mathrm{O}$ rats at rest and contractions elicited no changes $(P>0.05)$ from resting values in either group. However, the 
contracting $\mathrm{H}_{\mathrm{CAP}}$ was lower in $\mathrm{O}(0.19 \pm 0.02$ cells $/ \mu \mathrm{m})$ compared to $\mathrm{Y}(\mathrm{Y}: 0.25 \pm 0.02$ cells $/ \mu \mathrm{m} P<0.05$ ), and the transition to the contracting steady-state resulted in a lower $\Delta \mathrm{H}_{\mathrm{CAP}}$ in the $\mathrm{O}(-0.03 \pm 0.01$ cells $/ \mu \mathrm{m})$ versus $\mathrm{Y}(0.02 \pm 0.02$ cells $/ \mu \mathrm{m}, P<0.05)$ rats.

Contractions resulted in an increase in $\dot{Q} \mathrm{O}_{2 \mathrm{~m}}$ in $\mathrm{Y}(1615 \pm 402$ cells $/ \mathrm{s} / \mathrm{mm}, P<$ $0.05)$ with no change from resting values in $\mathrm{O}(780 \pm 121$ cells $/ \mathrm{s} / \mathrm{mm}, P>0.05)$ rats (Figure 4-4). Therefore, the $\Delta \dot{Q} \mathrm{O}_{2 \mathrm{~m}}$ from rest to contractions that was evident in the $\mathrm{Y}$ $(892 \pm 255$ cells $/ \mathrm{s} / \mathrm{mm}, P<0.05)$ did not occur in the $\mathrm{O}(-24.2 \pm 30$ cells $/ \mathrm{s} / \mathrm{mm})$ rats.

\section{RBC flux-velocity relationship}

In both age groups, there was a significant correlation $(P<0.05$ for both $)$ between $F_{\mathrm{RBC}}$ and $\mathrm{V}_{\mathrm{RBC}}$ as determined from mean values for rest and contractions from each muscle (Figure 4-5). The slope of this relationship dictates the capillary hematocrit and, accordingly, the steeper slope in the $\mathrm{O}$ compared to $\mathrm{Y}$ muscles reflects the reduced $\mathrm{H}_{\mathrm{CAP}}$ in $\mathrm{O}$ rats during contractions. 


\section{Table 4-1: Structural variables and capillary flow}

\begin{tabular}{lccccc}
\hline & \multicolumn{2}{c}{ Young } & \multicolumn{2}{c}{ Old } & \\
& $\underline{\text { Rest }}$ & $\underline{\text { Contractions }}$ & $\underline{\text { Rest }}$ & $\underline{\text { Contractions }}$ \\
Sarcomere length, $\mu \mathrm{m}$ & $2.7 \pm 0.1$ & $N / A$ & $2.7 \pm 0.1$ & N/A \\
Capillary diameter, $\mu \mathrm{m}$ & $5.5 \pm 0.3$ & N/A & $6.1 \pm 0.2$ & N/A \\
Countercurrent flow, \% & $21 \pm 3$ & N/A & $16 \pm 3$ & N/A \\
Lineal density, capillaries/mm & $32 \pm 2$ & N/A & $24 \pm 1^{*}$ & N/A \\
Flowing capillaries, \% & $96 \pm 2$ & $96 \pm 2$ & $93 \pm 2$ & $97 \pm 2$ \\
Flowing density, capillaries/mm & $31 \pm 3$ & $30 \pm 1$ & $22 \pm 1^{*}$ & $24 \pm 1^{*}$ \\
& & & & \\
\hline
\end{tabular}

Values are means \pm SE. Lineal density, lineal density of total capillaries; flowing density, lineal density of flowing capillaries. ${ }^{*} P<0.05$ compared to young. 
Figure 4-1: RBC flux
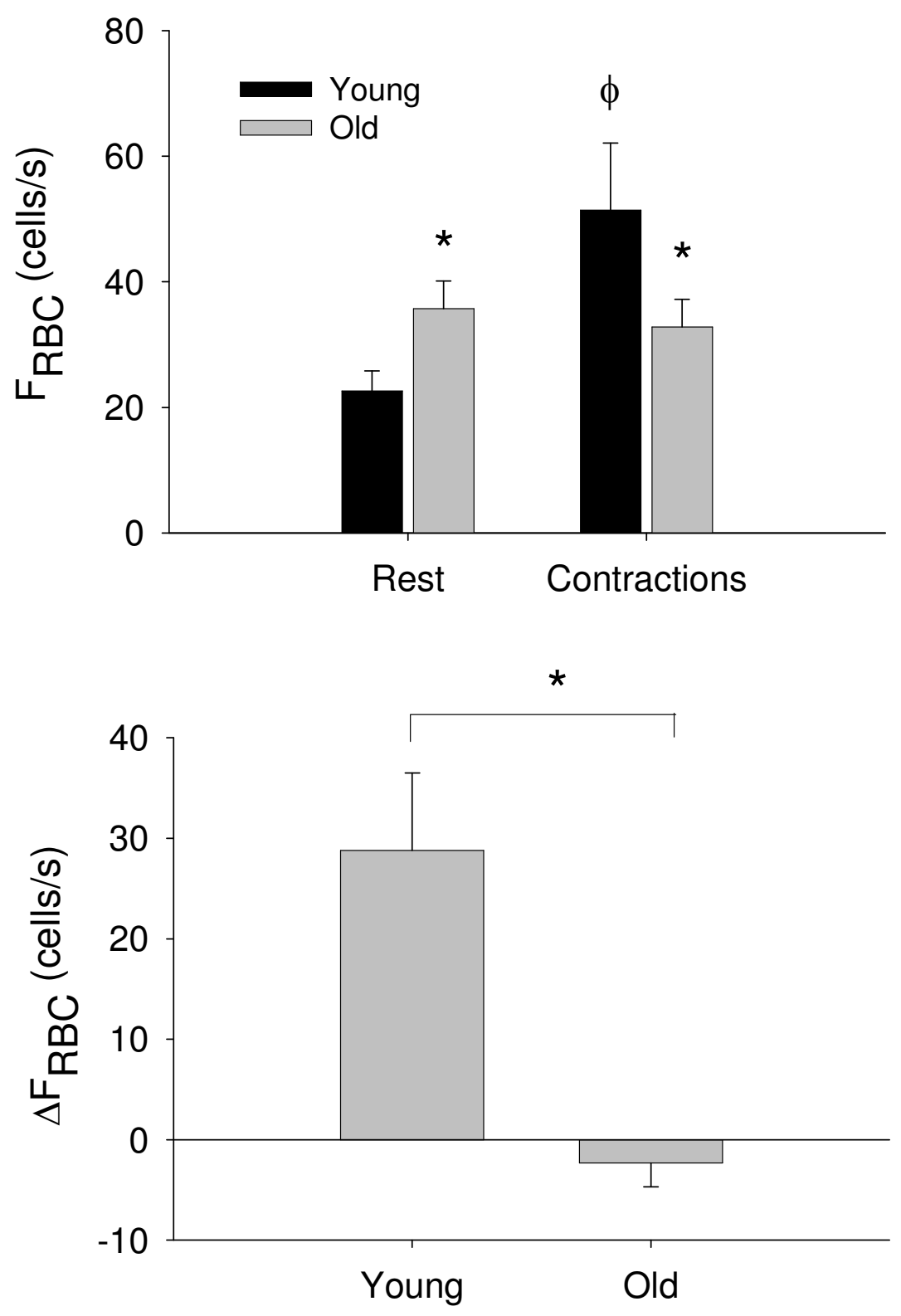

Top Panel: Capillary red blood cell flux $\left(\mathrm{F}_{\mathrm{RBC}}\right)$ measured at rest and during the contracting steady-state in $\mathrm{Y}$ and $\mathrm{O}$ animals. Bottom Panel: The change in $\mathrm{F}_{\mathrm{RBC}}$ from rest to contractions for both age groups. $* P<0.05$ compared to $\mathrm{Y}, \phi P<0.05$ compared to rest. 
Figure 4-2: RBC velocity
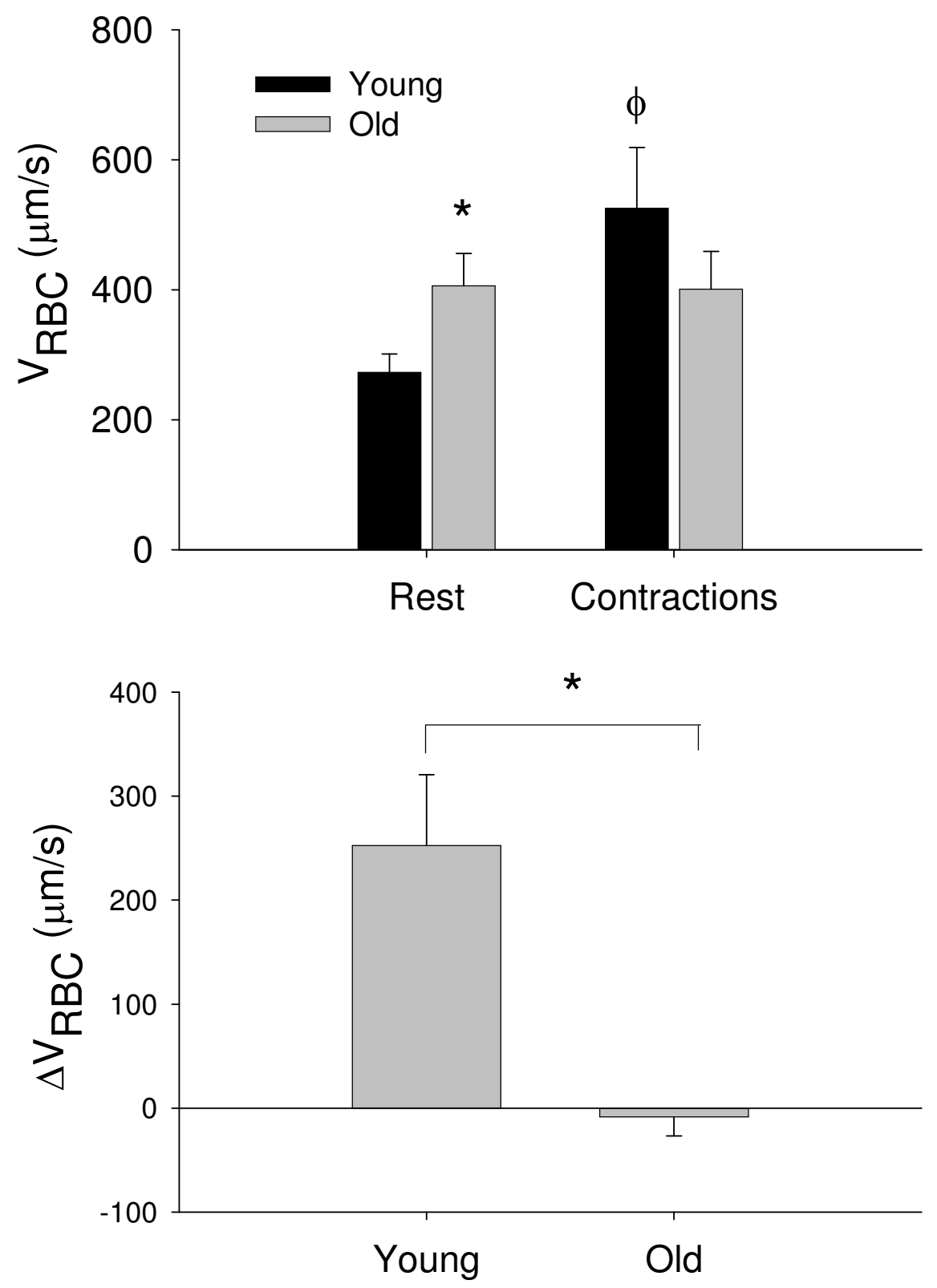

Top Panel: Capillary red blood cell velocity $\left(\mathrm{V}_{\mathrm{RBC}}\right)$ measured at rest and during the contracting steady-state in $\mathrm{Y}$ and $\mathrm{O}$ animals. Bottom Panel: The change in $\mathrm{V}_{\mathrm{RBC}}$ from rest to contractions for both age groups. $* P<0.05$ compared to $\mathrm{Y}, \phi P<0.05$ compared to rest. 
Figure 4-3: Capillary hematocrit
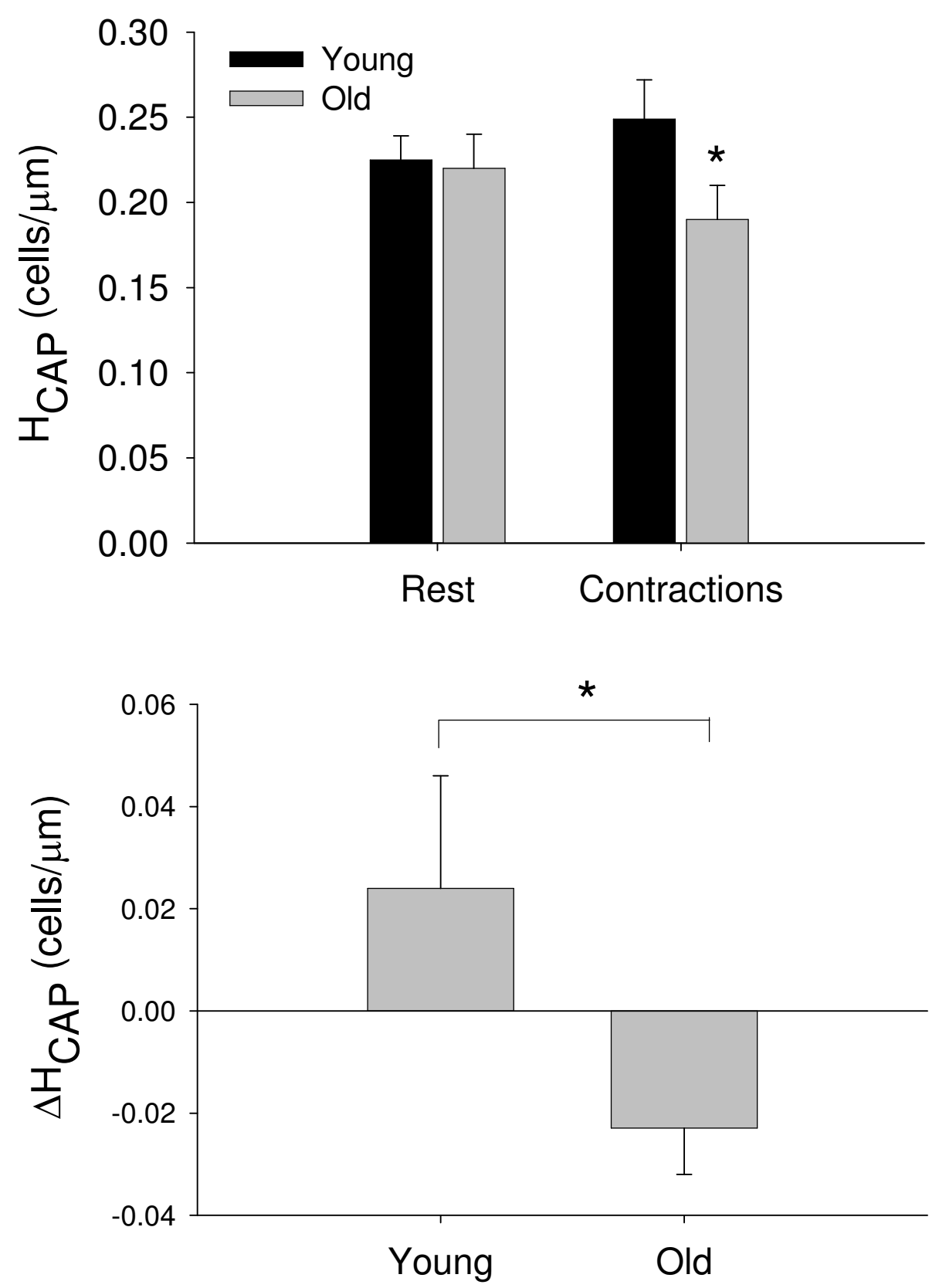

Top Panel: Capillary hematocrit $\left(\mathrm{H}_{\mathrm{CAP}}\right)$ measured at rest and during contractions in $\mathrm{Y}$ and $\mathrm{O}$ animals. Bottom Panel: The change in $\mathrm{H}_{\mathrm{CAP}}$ from rest to contractions for both age groups. $* P<0.05$ compared to $\mathrm{Y}$. 
Figure 4-4: Microvascular $\mathrm{O}_{2}$ delivery
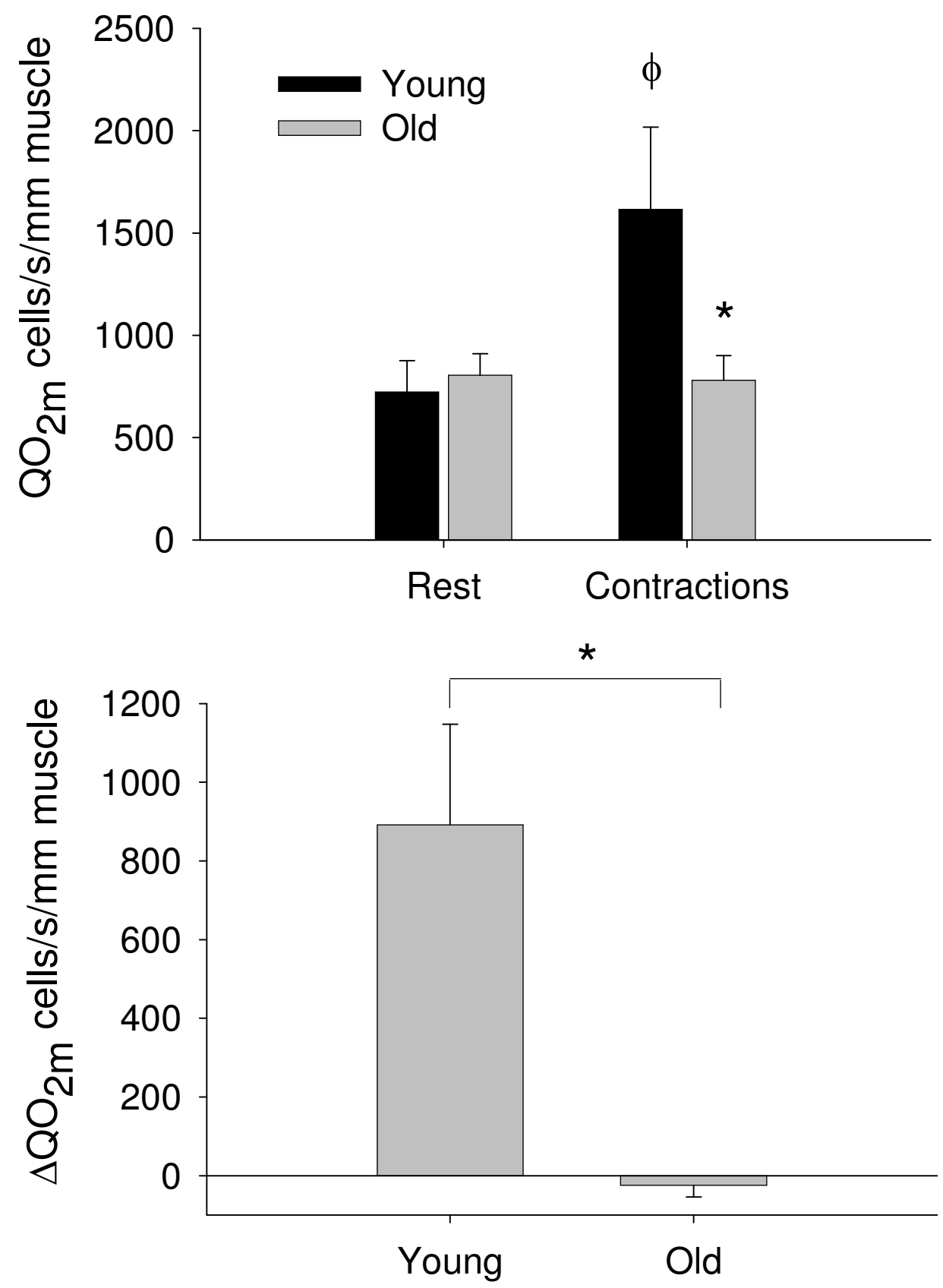

Top Panel: Microvascular $\mathrm{O}_{2}$ delivery $\left(\dot{Q} \mathrm{O}_{2 m}\right)$ measured at rest and during contractions in $\mathrm{Y}$ and $\mathrm{O}$ animals. Bottom Panel: The change in $\dot{Q} \mathrm{O}_{2 \mathrm{~m}}$ from rest to contractions for both age groups. $* P<0.05$ compared to $\mathrm{Y}, \phi P<0.05$ compared to rest. 
Figure 4-5: RBC flux-velocity relationship
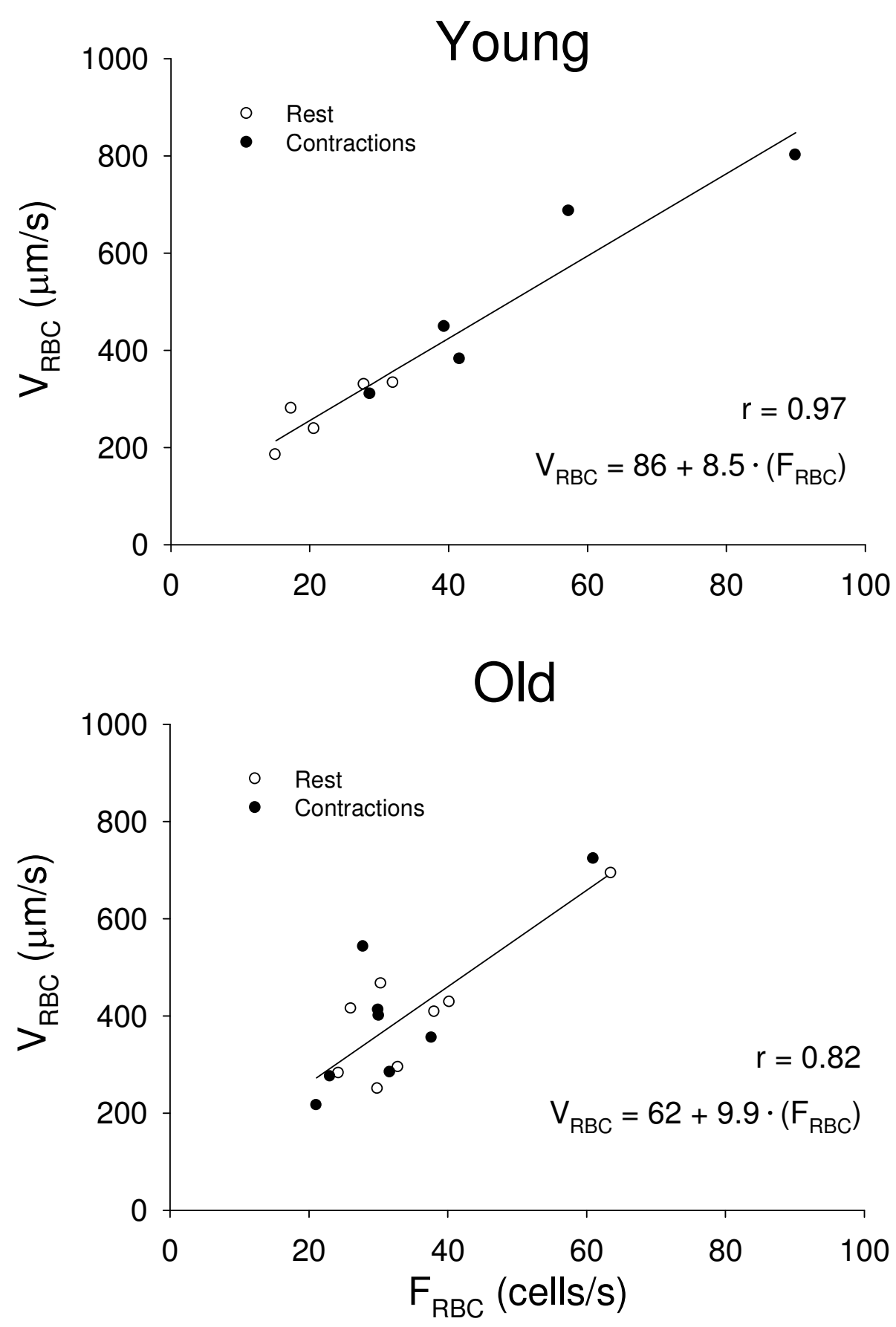

Relationship between red blood cell velocity $\left(\mathrm{V}_{\mathrm{RBC}}\right)$ and flux $\left(\mathrm{F}_{\mathrm{RBC}}\right)$ in $\mathrm{Y}$ (top panel) and O (bottom panel) muscles. Open symbols: rest; closed symbols: contractions. 


\section{CHAPTER 5 - Discussion}

The present investigation is the first to examine the effects of aging on skeletal muscle capillary hemodynamics during contractions. As demonstrated previously at rest, old muscles exhibit a reduced lineal density of RBC-flowing capillaries and within these capillaries there is an elevated $\mathrm{V}_{\mathrm{RBC}}$ and $\mathrm{F}_{\mathrm{RBC}}$ such that overall blood and $\mathrm{O}_{2}$ supply is not different from their young counterparts (Russell et al., 2003). The principal novel finding of the present investigation is that it is possible to actively contract the spinotrapezius muscle of aged animals without further increasing $\mathrm{V}_{\mathrm{RBC}}$ or $\mathrm{F}_{\mathrm{RBC}}$. Furthermore, the increased $\mathrm{H}_{\mathrm{CAP}}$ normally observed in contracting muscles of young animals was absent in old rats. Thus, compared with young rats, for an equivalent contractile stimulus, muscles from aged rats exhibit lower convective and diffusive capillary $\mathrm{O}_{2}$ delivery and any resultant attenuation in microcirculatory blood-muscle $\mathrm{O}_{2}$ flux is likely to contribute to the exercise intolerance evident in elderly populations.

\section{Comparisons to previous research}

In concert with the bulk of intravital microscopy studies, the present data indicates that the vast majority (i.e. $>80 \%$ ) of capillaries sustains RBC flow at rest, and this value was not different for young and old rats (Y: 96\%, O: 93\%). As demonstrated previously (Russell et al., 2003), the lineal density of total capillaries and the lineal density of flowing capillaries was reduced in old rats.

Rest: The resting values for $\mathrm{F}_{\mathrm{RBC}}$ and $\mathrm{V}_{\mathrm{RBC}}$ reported herein for young rats are similar to previously published values. In addition, and consistent with the findings of 
Russell et al. (Russell et al., 2003) for old rats, $\mathrm{F}_{\mathrm{RBC}}\left(35.7\right.$ cells/s) and $\mathrm{V}_{\mathrm{RBC}}(406 \mu \mathrm{m} / \mathrm{s})$ were both considerably higher than the established values for young rats (Sarelius \& Duling, 1982; Kindig \& Poole, 1998; Kindig et al., 2002; Russell et al., 2003). Indeed, the present $V_{\mathrm{RBC}}$ value is even higher than reported by Russell et al. (Russell et al., 2003) which may be the consequence of the slightly older age range (i.e., up to 30 vs. 28 months) in the rats in the present investigation. The $\mathrm{H}_{\mathrm{CAP}}$ of 0.23 and 0.22 cells $/ \mu \mathrm{m}$ for young and old rats, respectively, are close to our values (Y:27, O: 29 cells $/ \mu \mathrm{m}$ ) established for the F344xBN strain (Russell et al., 2003).

Contractions: During contractions, the young rats exhibited an increase in $\mathrm{F}_{\mathrm{RBC}}$ and $\mathrm{V}_{\mathrm{RBC}}$. In addition, the $\Delta \mathrm{H}_{\mathrm{CAP}}$ from rest to contractions was elevated in young compared to old rats. However, the difference was the result of a moderate increase in $\mathrm{H}_{\mathrm{CAP}}$ in the young combined with a small decrease in the old.

As mentioned previously, to our knowledge the literature contains no previous reports of capillary hemodynamics in aged muscle during contractions. Not-withstanding this fact, our data are consistent with those of Hammer and Boegehold (Hammer \& Boegehold, 2005) who found no increase in rat spinotrapezius arteriolar $\dot{Q}_{\mathrm{m}}$ in response to electrically-induced muscle contractions utilizing stimulation parameters similar to our own. In that investigation, $1 \mathrm{~Hz}$ contractions elicited no consistent increases in arteriolar diameter or $\mathrm{V}_{\mathrm{RBC}}$ in 24 month-old male Sprague-Dawley rats. In contrast, some studies have found no difference between $\dot{Q}_{\mathrm{m}}$ to exercising limbs in young and old subjects (Jasperse et al., 1994; Olive et al., 2002; Proctor et al., 2003b). However, the current literature is certainly not definitive on this issue (Wahren et al., 1974; Proctor et al., 1998; Proctor et al., 2003a) with differences possibly related to the activity level of the 
population studied, the function of the active muscle(s), and/or the intensity of the exercise. More importantly, recent evidence has established that large artery and limb blood flow may not be an appropriate analog of regional microvascular flow (Musch et al., 2004; Harper et al., 2006) which may explain the disparity between studies that have measured bulk arterial flow as distinct from microcirculatory flow (present results; Hammer \& Boegehold, 2005).

\section{Implications for blood-muscle $\mathrm{O}_{2}$ transfer}

The $\mathrm{O}_{2}$ extraction analysis initially developed by Piiper and Scheid (Piiper \& Scheid, 1981), and adapted for skeletal muscle by Wagner and colleagues (Roca et al., 1992), can be used to predict the effect of aging on fractional $\mathrm{O}_{2}$ extraction within the microcirculation. Specifically, blood-muscle $\mathrm{O}_{2}$ flux is primarily determined by the relationship between $\mathrm{DO}_{2}$ and $\dot{Q}_{\mathrm{m}}$ such that $\dot{\mathrm{V}} \mathrm{O}_{2 \mathrm{~m}}=\dot{Q}_{\mathrm{m}}\left(1-e^{-\mathrm{DO}_{2} / \mathrm{BQ}_{\mathrm{m}}}\right)$, and therefore, $\dot{\mathrm{V}} \mathrm{O}_{2 \mathrm{~m}} / \dot{Q}_{\mathrm{m}}=\mathrm{O}_{2}$ extraction $=1-e^{-\mathrm{DO}_{2} / \mathrm{QQ}_{\mathrm{m}}}$, where $\mathrm{DO}_{2}$ is the diffusing capacity for $\mathrm{O}_{2}$ and $\beta$ is the slope of the $\mathrm{O}_{2}$ dissociation curve in the physiologically relevant range. In the microcirculation, $\mathrm{F}_{\mathrm{RBC}}$ is the instantaneous measurement of $\dot{Q}_{\mathrm{m}}$, therefore, $\mathrm{O}_{2}$ extraction $=1-e^{-\mathrm{DO}_{2} / \mathrm{B} \mathrm{RBC}_{\mathrm{RBC}}}$. Substantial evidence supports that the principal site of $\mathrm{O}_{2}$ diffusion resistance lies between the RBC and the immediate subsarcolemmal space (Gayeski \& Honig, 1983; Hepple et al., 2000), therefore, $\mathrm{DO}_{2}$ will be primarily determined by the total capillary surface area available for $\mathrm{O}_{2}$ exchange (Mathieu-Costello et al., 1991) and the number of RBCs present along the capillary length (Groebe \& Thews, 1990). At rest, the similar $\mathrm{H}_{\mathrm{CAP}}$ present between young and old rats suggests that the $\mathrm{DO}_{2}$ per capillary is maintained with aging. However, the elevated $\mathrm{F}_{\mathrm{RBC}}$ at rest reduces the $\mathrm{DO}_{2} / \beta \mathrm{F}_{\mathrm{RBC}}$ ratio 
within each capillary, and therefore diminishes the reserve capacity to increase $\mathrm{O}_{2}$ extraction. More importantly, the aging-induced reduction in the lineal density of flowing capillaries would reduce the mean $\mathrm{DO}_{2}$ per muscle area or volume. This has important implications for exercise in that, if $>90 \%$ of capillaries are supporting RBC flow at rest, the capacity for $\mathrm{DO}_{2}$ to increase during exercise is limited to increases in $\mathrm{H}_{\mathrm{CAP}}$ (i.e. longitudinal recruitment of capillary surface area along already-flowing capillaries). Our data indicate that mild-moderate contractions of aged muscle are accompanied by a significantly lower $\mathrm{H}_{\mathrm{CAP}}$ (and therefore $\mathrm{DO}_{2}$ ) compared to young muscle. This scenario would be expected to compromise the potential for elevating blood-myocyte $\mathrm{O}_{2}$ flux and, therefore, muscle oxidative function.

Previously, we hypothesized that if the elevated $V_{R B C}$ evident in old muscles at rest lead to a correspondingly faster $V_{R B C}$ during high intensity exercise, the resultant shortening of $\mathrm{RBC}$ transit time might necessitate a reduction of intracellular $\mathrm{PO}_{2}$ to achieve the required level of blood-muscle $\mathrm{O}_{2}$ flux (Poole et al., 2006). Because the contractions implemented in the present investigation did not elicit any increase in either perfusive or diffusive tissue $\mathrm{O}_{2}$ transport, this mechanism (i.e., reduced intracellular $\mathrm{PO}_{2}$ ) will have been solely responsible for augmenting blood-muscle $\mathrm{O}_{2}$ flux via greater fractional $\mathrm{O}_{2}$ extraction. Such a mechanism at both moderate and high contraction intensities may be responsible, in part, for the slowed $\dot{\mathrm{VO}}_{2}$ kinetics (Babcock et al., 1994; Chilibeck et al., 1995) and increased $\mathrm{O}_{2}$ deficit evident in elderly populations. 


\section{Mechanisms of microcirculatory dysfunction}

Following the onset of contractions, the increase in $\dot{Q}_{\mathrm{m}}$ occurs in a distinct biphasic response (Kindig et al., 2002). The initial, rapid phase of the increase (phase I) is generally attributed to muscle pump combined with rapid vasodilation that may potentially be mediated, in part, by compressive forces acting on the vasculature in addition to $\mathrm{K}^{+}$released from the contracting myocytes accumulating in the muscle interstitium (Bacchus et al., 1981; Tschakovsky et al., 2004; Clifford, 2007). Phase I lasts $15-20$ seconds and is followed by a more pronounced phase II which is attributed primarily to endothelial-mediated vasodilatory mechanisms that include NO, prostacyclin, endothelial derived hyperpolarizing factor, primarily reflecting metabolic regulation/feedback control. The present observation that contractions resulted in no discernible alteration in capillary hemodynamics in aged muscle requires that aging impacts significantly both the muscle pump effect and arteriolar dilation.

The absence of any increase in $\mathrm{F}_{\mathrm{RBC}}$ (Figure 5-1) requires that the muscle pump is ineffectual in the spinotrapezius muscle of old rats. It may be argued that this muscle might not be expected to evoke a muscle pump effect due to the absence of a substantial muscle belly and the non-physiological muscle fiber recruitment pattern elicited by electrical stimulation. However, Kindig et al. (Kindig et al., 2002) observed that a contraction stimulus identical to the one utilized herein results in a biphasic increase in $\mathrm{F}_{\mathrm{RBC}}$ in young rats, with the instantaneous (i.e. within $\sim 1 \mathrm{~s}$ ) elevation in $\mathrm{F}_{\mathrm{RBC}}$ normally attributed, in part, to a muscle pumping action (Tschakovsky et al., 1996).

Healthy aging results in a decreased compliance of the venous vessels. It is possible that at mild-moderate contraction intensities, aged skeletal muscle is unable to 
produce the force required to compress the stiffened capacitance vessels and is, therefore, unable to produce negative venular pressures upon muscle relaxation. Additionally, the chronic high microvascular flow (increased $\mathrm{F}_{\mathrm{RBC}}$ and $\mathrm{V}_{\mathrm{RBC}}$ ) at rest in aged rats may offset the muscle pump effect by rapidly refilling the venules and minimizing any transient gain in the arteriolar-venule pressure gradient. This scenario was originally suggested by Tschakovsky and Sheriff (Tschakovsky \& Sheriff, 2004) as a possible explanation for the fact that the muscle pump did not further increase the exercise hyperemic response in the dog hindlimb when maximal pharmacological vasodilation was induced prior to the onset of conscious treadmill exercise (Hamann et al., 2003). Old rat muscles might be subjected to both of these effects.

During exercise, skeletal muscle vascular tone is controlled by both feed-forward (e.g., conducted, shear-stress induced), and feedback (e.g., metabolic regulation) mechanisms both of which may become impaired to different degrees with advancing age. For example, aging is associated with reductions in functional sympatholysis (Dinenno et al., 2005; Parker et al., 2007), myogenic control (Muller-Delp et al., 2002a), and contraction-induced rapid vessel relaxation (Carlson et al., 2008). Moreover, endothelium-dependent vasodilation is impaired (Muller-Delp et al., 2002b), with the dysfunction likely occurring preferentially in arterioles supplying oxidative but not glycolytic muscles (Woodman et al., 2002). While several discrete signaling pathways contribute to the endothelium-dependent regulation of vascular tone, $\mathrm{NO}$ appears to play a principal role, particularly in oxidative muscles (Hirai et al., 1994). It is wellestablished that the NO-mediated dilation is reduced in aged vessels when compared to younger counterparts. For example, aging reduces NO-mediated vasodilation in response 
to contractions in the skeletal muscles of humans (Taddei et al., 2000; Schrage et al., 2007) and rats (Muller-Delp et al., 2002b; Woodman et al., 2002; Spier et al., 2004).

However, what remains unclear is whether or not at rest the aged vasculature has already utilized some of its dilatory capacity in order to accommodate the same bulk flow through fewer resistance vessels i.e., greater flow, and therefore dilation, per vessel (Behnke et al., 2006). This may represent a reduction in the reserve capacity of one or more vasoregulatory pathways (i.e. endothelium-independent dilation) in preference to dilatory function per se as reported by others (Muller-Delp et al., 2002b; Woodman et al., 2002). The combination of these impaired vasoregulatory mechanisms is likely to require higher strength contractions to increase arteriolar flow above resting values and, importantly, will significantly compromise the reserve capacity to increase arteriolar flow during maximal exercise.

\section{Methodological considerations}

The stimulation parameters utilized herein are identical to those used previously in rats and allow for the restoration of visual clarity in $\sim 15$ frames between contractions a necessary condition for determination of capillary hemodynamics. Higher-intensity maximal-strength tetanic contractions would limit hemodynamic assessment to the immediate post-contraction recovery period. Recovery of hemodynamic variables is sufficiently fast that such procedures would obviate measurement of true contracting values if, of course, they were different from rest (Ferreira et al., 2006). Whereas we would predict that higher-intensity contractions would result in increases in capillary hemodynamics in old muscles, albeit to a lesser extent than that of younger muscles, we do not, at present, have the technical ability to conduct these studies. Further 
methodological considerations regarding the rat spinotrapezius preparation have been discussed in detail previously (Bailey et al., 2000; Kindig et al., 2002).

\section{Conclusion}

This study is the first to demonstrate that old age results in significant alterations in capillary hemodynamics in the rat spinotrapezius muscle during the mild-moderate metabolic stresses associated with submaximal electrically-induced $1 \mathrm{~Hz}$ twitch contractions. Specifically, from rest to the contracting steady-state, when utilizing stimulation parameters that result in increased $\mathrm{F}_{\mathrm{RBC}}, \mathrm{V}_{\mathrm{RBC}}, \mathrm{H}_{\mathrm{CAP}}$ and $\dot{Q} \mathrm{O}_{2 \mathrm{~m}}$ in the spinotrapezius muscle of young animals, the aged rat spinotrapezius evidences no significant increases in these variables. The attenuation of increases in both conductive and diffusive measures of $\mathrm{O}_{2}$ transport in aged muscle capillaries has significant implications for blood-muscle $\mathrm{O}_{2}$ delivery, and therefore, the ability for elderly individuals to sustain muscle oxidative function during dynamic exercise. 


\section{Figure 5-1: RBC flux dynamics}

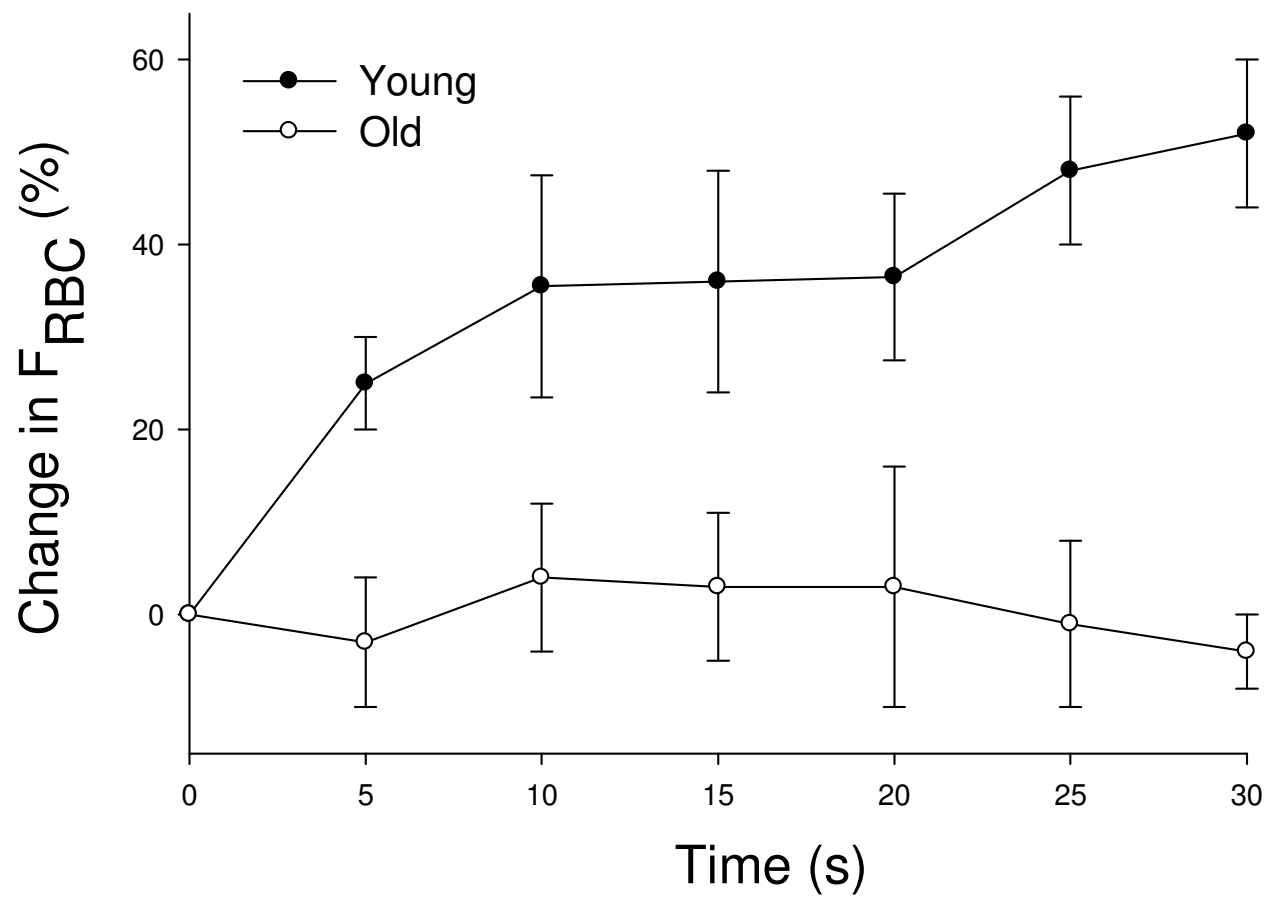

The percent change in red blood cell flux $\left(\mathrm{F}_{\mathrm{RBC}}\right)$ upon the initiation of contractions in 5 randomly selected capillaries from old muscles. Young data is the average $\mathrm{F}_{\mathrm{RBC}}$ response from previously published young healthy controls (Kindig et al., 2002; Richardson et al., 2003). 


\section{References}

Altman P \& Dittmer D. (1974). Biological Data Book (2nd ed.). FASEB, Bethesda, MD.

Babcock MA, Paterson DH, Cunningham DA \& Dickinson JR. (1994). Exercise ontransient gas exchange kinetics are slowed as a function of age. Med Sci Sports Exerc 26, 440-446.

Bacchus A, Gamble G, Anderson D \& Scott J. (1981). Role of the myogenic response in exercise hyperemia. Microvasc Res 21, 92-102.

Bailey JK, Kindig CA, Behnke BJ, Musch TI, Schmid-Schoenbein GW \& Poole DC. (2000). Spinotrapezius muscle microcirculatory function: effects of surgical exteriorization. Am J Physiol Heart Circ Physiol 279, H3131-3137.

Barstow TJ, Lamarra N \& Whipp BJ. (1990). Modulation of muscle and pulmonary $\mathrm{O}_{2}$ uptakes by circulatory dynamics during exercise. J Appl Physiol 68, 979-989.

Behnke BJ, Barstow TJ, Kindig CA, McDonough P, Musch TI \& Poole DC. (2002). Dynamics of oxygen uptake following exercise onset in rat skeletal muscle. Respir Physiol Neurobiol 133, 229-239.

Behnke BJ, Delp MD, Dougherty PJ, Musch TI \& Poole DC. (2005). Effects of aging on microvascular oxygen pressures in rat skeletal muscle. Respir Physiol Neurobiol 146, 259-268.

Behnke BJ, Prisby RD, Lesniewski LA, Donato AJ, Olin HM \& Delp MD. (2006). Influence of ageing and physical activity on vascular morphology in rat skeletal muscle. J Physiol 575, 617-626.

Carlson RE, Kirby BS, Voyles WF \& Dinenno FA. (2008). Evidence for impaired skeletal muscle contraction-induced rapid vasodilation in aging humans. Am J Physiol Heart Circ Physiol 294, H1963-1970.

Chilibeck PD, Paterson DH \& Cunningham DA. (1995). Effects of age on $\mathrm{VO}_{2}$ kinetics during calf and cycling exercise. Adv Exp Med Biol 393, 195-200.

Clifford PS. (2007). Skeletal muscle vasodilatation at the onset of exercise. J Physiol 583, 825-833.

Conley KE, Jubrias SA \& Esselman PC. (2000). Oxidative capacity and ageing in human muscle. J Physiol 526 Pt 1, 203-210. 
Delp MD \& Duan C. (1996). Composition and size of type I, IIA, IID/X, and IIB fibers and citrate synthase activity of rat muscle. J Appl Physiol 80, 261-270.

Dinenno FA, Masuki S \& Joyner MJ. (2005). Impaired modulation of sympathetic alphaadrenergic vasoconstriction in contracting forearm muscle of ageing men. $J$ Physiol 567, 311-321.

Donato AJ, Uberoi A, Wray DW, Nishiyama S, Lawrenson L \& Richardson RS. (2006). Differential effects of aging on limb blood flow in humans. Am J Physiol Heart Circ Physiol 290, H272-278.

Federspiel WJ \& Popel AS. (1986). A theoretical analysis of the effect of the particulate nature of blood on oxygen release in capillaries. Microvasc Res 32, 164-189.

Ferreira LF, Padilla DJ, Musch TI \& Poole DC. (2006). Temporal profile of rat skeletal muscle capillary haemodynamics during recovery from contractions. J Physiol 573, 787-797.

Folkow B \& Svanborg A. (1993). Physiology of cardiovascular aging. Physiol Rev 73, 725-764.

Gayeski TE \& Honig CR. (1983). Direct measurement of intracellular $\mathrm{O}_{2}$ gradients; role of convection and myoglobin. Adv Exp Med Biol 159, 613-621.

Grassi B. (2000). Skeletal muscle $\mathrm{VO}_{2}$ on-kinetics: set by $\mathrm{O}_{2}$ delivery or by $\mathrm{O}_{2}$ utilization? New insights into an old issue. Med Sci Sports Exerc 32, 108-116.

Groebe K \& Thews G. (1986). Theoretical analysis of oxygen supply to contracted skeletal muscle. Adv Exp Med Biol 200, 495-514.

Groebe K \& Thews G. (1990). Calculated intra- and extracellular $\mathrm{PO}_{2}$ gradients in heavily working red muscle. Am J Physiol 259, H84-92.

Hamann JJ, Valic Z, Buckwalter JB \& Clifford PS. (2003). Muscle pump does not enhance blood flow in exercising skeletal muscle. J Appl Physiol 94, 6-10.

Hammer LW \& Boegehold MA. (2005). Functional hyperemia is reduced in skeletal muscle of aged rats. Microcirculation 12, 517-526.

Harper AJ, Ferreira LF, Lutjemeier BJ, Townsend DK \& Barstow TJ. (2006). Human femoral artery and estimated muscle capillary blood flow kinetics following the onset of exercise. Exp Physiol 91, 661-671.

Hepple RT, Hagen JL, Krause DJ \& Jackson CC. (2003). Aerobic power declines with aging in rat skeletal muscles perfused at matched convective $\mathrm{O}_{2}$ delivery. $J \mathrm{Appl}$ Physiol 94, 744-751. 
Hepple RT, Hogan MC, Stary C, Bebout DE, Mathieu-Costello O \& Wagner PD. (2000). Structural basis of muscle $\mathrm{O}_{2}$ diffusing capacity: evidence from muscle function in situ. J Appl Physiol 88, 560-566.

Hepple RT \& Vogell JE. (2004). Anatomic capillarization is maintained in relative excess of fiber oxidative capacity in some skeletal muscles of late middle-aged rats. $J$ Appl Physiol 96, 2257-2264.

Hirai T, Visneski MD, Kearns KJ, Zelis R \& Musch TI. (1994). Effects of NO synthase inhibition on the muscular blood flow response to treadmill exercise in rats. $J$ Appl Physiol 77, 1288-1293.

Irion GL, Vasthare US \& Tuma RF. (1987). Age-related change in skeletal muscle blood flow in the rat. $J$ Gerontol 42, 660-665.

Jasperse JL, Seals DR \& Callister R. (1994). Active forearm blood flow adjustments to handgrip exercise in young and older healthy men. $J$ Physiol 474, 353-360.

Kano Y, Padilla D, Hageman KS, Poole DC \& Musch TI. (2004). Downhill running: a model of exercise hyperemia in the rat spinotrapezius muscle. J Appl Physiol 97, 1138-1142.

Kindig CA, Musch TI, Basaraba RJ \& Poole DC. (1999). Impaired capillary hemodynamics in skeletal muscle of rats in chronic heart failure. J Appl Physiol 87, 652-660.

Kindig CA \& Poole DC. (1998). A comparison of the microcirculation in the rat spinotrapezius and diaphragm muscles. Microvasc Res 55, 249-259.

Kindig CA \& Poole DC. (1999). Effects of skeletal muscle sarcomere length on in vivo capillary distensibility. Microvasc Res 57, 144-152.

Kindig CA \& Poole DC. (2001). Sarcomere length-induced alterations of capillary hemodynamics in rat spinotrapezius muscle: vasoactive vs passive control. Microvasc Res 61, 64-74.

Kindig CA, Richardson TE \& Poole DC. (2002). Skeletal muscle capillary hemodynamics from rest to contractions: implications for oxygen transfer. J Appl Physiol 92, 2513-2520.

Kindig CA, Sexton WL, Fedde MR \& Poole DC. (1998). Skeletal muscle microcirculatory structure and hemodynamics in diabetes. Respir Physiol 111, 163-175. 
Kobayashi H, Pelster B, Piiper J \& Scheid P. (1990). Counter-current blood flow in tissues: protection against adverse effects. Adv Exp Med Biol 277, 3-11.

Lakatta EG. (1990). Changes in cardiovascular function with aging. Eur Heart J 11 Suppl C, 22-29.

Lawrenson L, Poole JG, Kim J, Brown C, Patel P \& Richardson RS. (2003). Vascular and metabolic response to isolated small muscle mass exercise: effect of age. Am J Physiol Heart Circ Physiol 285, H1023-1031.

Leek BT, Mudaliar SR, Henry R, Mathieu-Costello O \& Richardson RS. (2001). Effect of acute exercise on citrate synthase activity in untrained and trained human skeletal muscle. Am J Physiol Regul Integr Comp Physiol 280, R441-447.

Magnusson G, Kaijser L, Isberg B \& Saltin B. (1994). Cardiovascular responses during one- and two-legged exercise in middle-aged men. Acta Physiol Scand 150, 353362.

Mathieu-Costello O, Ellis CG, Potter RF, MacDonald IC \& Groom AC. (1991). Muscle capillary-to-fiber perimeter ratio: morphometry. Am J Physiol 261, H1617-1625.

Mathieu-Costello O, Ju Y, Trejo-Morales M \& Cui L. (2005). Greater capillary-fiber interface per fiber mitochondrial volume in skeletal muscles of old rats. $J$ Appl Physiol 99, 281-289.

Mathieu-Costello O, Tyml K \& Poole DC. (1998). Cross-sectional shape of muscle capillaries. FASEB J 12, A11.

McGuire DK, Levine BD, Williamson JW, Snell PG, Blomqvist CG, Saltin B \& Mitchell JH. (2001). A 30-year follow-up of the Dallas Bedrest and Training Study: I. Effect of age on the cardiovascular response to exercise. Circulation 104, 13501357.

Muller-Delp J, Spier SA, Ramsey MW, Lesniewski LA, Papadopoulos A, Humphrey JD \& Delp MD. (2002a). Effects of aging on vasoconstrictor and mechanical properties of rat skeletal muscle arterioles. Am J Physiol Heart Circ Physiol 282, H1843-1854.

Muller-Delp JM. (2006). Aging-induced adaptations of microvascular reactivity. Microcirculation 13, 301-314.

Muller-Delp JM, Spier SA, Ramsey MW \& Delp MD. (2002b). Aging impairs endothelium-dependent vasodilation in rat skeletal muscle arterioles. Am J Physiol Heart Circ Physiol 283, H1662-1672. 
Musch TI, Eklund KE, Hageman KS \& Poole DC. (2004). Altered regional blood flow responses to submaximal exercise in older rats. J Appl Physiol 96, 81-88.

Ogawa T, Spina RJ, Martin WH, 3rd, Kohrt WM, Schechtman KB, Holloszy JO \& Ehsani AA. (1992). Effects of aging, sex, and physical training on cardiovascular responses to exercise. Circulation 86, 494-503.

Olive JL, DeVan AE \& McCully KK. (2002). The effects of aging and activity on muscle blood flow. Dyn Med 1, 2.

Padilla DJ, McDonough P, Behnke BJ, Kano Y, Hageman KS, Musch TI \& Poole DC. (2006). Effects of Type II diabetes on capillary hemodynamics in skeletal muscle. Am J Physiol Heart Circ Physiol 291, H2439-2444.

Parker BA, Smithmyer SL, Jarvis SS, Ridout SJ, Pawelczyk JA \& Proctor DN. (2007). Evidence for reduced sympatholysis in leg resistance vasculature of healthy older women. Am J Physiol Heart Circ Physiol 292, H1148-1156.

Petrella JK, Kim JS, Tuggle SC, Hall SR \& Bamman MM. (2005). Age differences in knee extension power, contractile velocity, and fatigability. J Appl Physiol 98, 211-220.

Piiper J \& Scheid P. (1981). Model for capillary-alveolar equilibration with special reference to $\mathrm{O}_{2}$ uptake in hypoxia. Respir Physiol 46, 193-208.

Poole D, Behnke B \& Musch T. (2006). Capillary hemodynamics and oxygen pressures in the aging microcirculation. Microcirculation 13, 289-299.

Poole DC, Musch TI \& Kindig CA. (1997). In vivo microvascular structural and functional consequences of muscle length changes. Am J Physiol 272, H21072114.

Poole JG, Lawrenson L, Kim J, Brown C \& Richardson RS. (2003). Vascular and metabolic response to cycle exercise in sedentary humans: effect of age. Am J Physiol Heart Circ Physiol 284, H1251-1259.

Proctor DN, Koch DW, Newcomer SC, Le KU \& Leuenberger UA. (2003a). Impaired leg vasodilation during dynamic exercise in healthy older women. J Appl Physiol 95, 1963-1970.

Proctor DN, Newcomer SC, Koch DW, Le KU, MacLean DA \& Leuenberger UA. (2003b). Leg blood flow during submaximal cycle ergometry is not reduced in healthy older normally active men. J Appl Physiol 94, 1859-1869.

Proctor DN \& Parker BA. (2006). Vasodilation and vascular control in contracting muscle of the aging human. Microcirculation 13, 315-327. 
Proctor DN, Shen PH, Dietz NM, Eickhoff TJ, Lawler LA, Ebersold EJ, Loeffler DL \& Joyner MJ. (1998). Reduced leg blood flow during dynamic exercise in older endurance-trained men. J Appl Physiol 85, 68-75.

Richardson TE, Kindig CA, Musch TI \& Poole DC. (2003). Effects of chronic heart failure on skeletal muscle capillary hemodynamics at rest and during contractions. J Appl Physiol 95, 1055-1062.

Roca J, Agusti AG, Alonso A, Poole DC, Viegas C, Barbera JA, Rodriguez-Roisin R, Ferrer A \& Wagner PD. (1992). Effects of training on muscle $\mathrm{O}_{2}$ transport at $\mathrm{VO}_{2 \max }$. J Appl Physiol 73, 1067-1076.

Russell JA, Kindig CA, Behnke BJ, Poole DC \& Musch TI. (2003). Effects of aging on capillary geometry and hemodynamics in rat spinotrapezius muscle. Am J Physiol Heart Circ Physiol 285, H251-258.

Sarelius IH \& Duling BR. (1982). Direct measurement of microvessel hematocrit, red cell flux, velocity, and transit time. Am J Physiol 243, H1018-1026.

Schrage WG, Eisenach JH \& Joyner MJ. (2007). Ageing reduces nitric-oxide- and prostaglandin-mediated vasodilatation in exercising humans. J Physiol 579, 227236.

Spier SA, Delp MD, Meininger CJ, Donato AJ, Ramsey MW \& Muller-Delp JM. (2004). Effects of ageing and exercise training on endothelium-dependent vasodilatation and structure of rat skeletal muscle arterioles. J Physiol 556, 947-958.

Taddei S, Galetta F, Virdis A, Ghiadoni L, Salvetti G, Franzoni F, Giusti C \& Salvetti A. (2000). Physical activity prevents age-related impairment in nitric oxide availability in elderly athletes. Circulation 101, 2896-2901.

Tschakovsky ME, Rogers AM, Pyke KE, Saunders NR, Glenn N, Lee SJ, Weissgerber T $\&$ Dwyer EM. (2004). Immediate exercise hyperemia in humans is contraction intensity dependent: evidence for rapid vasodilation. J Appl Physiol 96, 639-644.

Tschakovsky ME \& Sheriff DD. (2004). Immediate exercise hyperemia: contributions of the muscle pump vs. rapid vasodilation. J Appl Physiol 97, 739-747.

Tschakovsky ME, Shoemaker JK \& Hughson RL. (1996). Vasodilation and muscle pump contribution to immediate exercise hyperemia. Am J Physiol 271, H1697-1701.

Tyml K, Mathieu-Costello O \& Budreau CH. (1992). Distribution of red blood cell velocity in capillary network, and endothelial ultrastructure, in aged rat skeletal muscle. Microvasc Res 44, 1-13. 
Wahren J, Saltin B, Jorfeldt L \& Pernow B. (1974). Influence of age on the local circulatory adaptation to leg exercise. Scand J Clin Lab Invest 33, 79-86.

Woodman CR, Price EM \& Laughlin MH. (2002). Aging induces muscle-specific impairment of endothelium-dependent dilation in skeletal muscle feed arteries. $J$ Appl Physiol 93, 1685-1690. 